\title{
Province of the Gut-Probiotics
}

\section{Anjana Agarwal ${ }^{*}$}

Nutritionist and Aromatherapist, SNDT Women's University, Mumbai, India

*Corresponding author: Anjana Agarwal, Nutritionist and Aromatherapist, SNDT Women's University, Mumbai, India, Tel: +919958593488; E-mail: dranjanaagarwal@gmail.com

Received date: August 23, 2017; Accepted date: August 24, 2017; Published date: August 30, 2017

Copyright: @ 2017 Agarwal A. This is an open-access article distributed under the terms of the Creative Commons Attribution License, which permits unrestricted use, distribution, and reproduction in any medium, provided the original author and source are credited.

Citation: Agarwal A (2017) Province of the Gut-Probiotics. J Nutr Disorders Ther 7: e133. doi:10.4172/2161-0509.1000e133

\section{Editorial}

Billions of friendly microorganisms naturally populate the gut to ensure health and well-being of the person. These bacterial colonies have captured the scientific platforms and the global market of the health supplements. Since ages fermented food products were appreciated not only for their organoleptic properties but for their health significance. These are valuable owing to numerous species of lactobacillus and bifidobacteria and others. In 1906 Henry Tissier, a French paediatrician observed that gut microflora of healthy children was dominated by healthy bacteria (bifid) and the bacterial count of good bacteria was low in children having diarrhoea. In 1907, Eli Metchnikoff, 'father of probiotics", Nobel Prize winner suggested the possibility of modification of gut microflora. The work of two gave the scientific suggestion with regard to significant role of bacteria on health but the word "probiotic" was not coined until 1960s. Many scientists contributed in this area and the Expert group of WHO/FAO (2001) eventually gave a definition of probiotic, i.e. "live microorganisms which when administered in adequate amounts confer heath benefits on the host".

Bifidus factor was found in Mother's milk leading to the growth of bifidobacteria in the intestine of new born responsible for digestion of milk; long term immunity to the child and prevention of growth of rotavirus causing infantile diarrhoea. Caesarean babies and bottle fed babies have relatively low Bifidobacteria in their system hence at high risk of diseases.

What is role of microorganisms in our body? They are present throughout our alimentary canal. The integrity of epithelial lining of the gut is crucial in maintaining the micro ecology of the system as it directly influences the absorption and transport of nutrients throughout the body. Intestinal flora helps in synthesizing some of the $\mathrm{B}$ vitamins and vitamin; nourishes the epithelial lining by butyric acid, one of the short chain fatty acids. Healthy mucosal lining of the gut is also responsible for stimulation of autonomic nervous system and production of hormones associated with GI tract and the low grade inflammation that is linked to many diseases [1].

Under pathological conditions there is drastic alteration in microbiota. High sugar and fried food, use of antibiotics, radiation, bacterial and parasitic infection, Candida yeast, environment pollutants, stress and age greatly influence it. Toxins, pollution, fungi, virus, parasites and bacteria alter the micro ecology of the gut and depreciate the immunity. Probiotics through strains of Lactobacilli and bifid bacteria help to bring balance in the gut flora. They work like crusaders to boost the immunity, protect the body from environmental threats and prevent pathogenesis of infectious and inflammatory diseases. They exhibit beneficial effects diarrhea acute including drug induced diarrhea, inflammatory bowel disease (IBD), ulcerative colitis, Candida infection, lactose intolerance and colon cancer.

Use of probiotics is a new approach to traditional system of food processing and consumption. They can be used in several fermented and preserved foods such as Indian curd, yogurt, and kefir, soy products like temphe, miso, and vegetable products like sauerkraut, kimchi, kombucha, and probiotic products like yoghurt, ice cream, cheddar cheese and sour cream. Foods containing soluble fiber, insoluble soluble fiber or resistance starch support maintenance of healthy gut bacteria. Researchers are developing health food products using food ingredients and microbial cultures. Probiotics supplements are commercially available in the form of sachets, capsules and tablets. Suitable storage conditions and shelf life of supplements must be reflected and noted on labelling as per WHO guidelines [2].

Dose of anything is critical so it is true with probiotic. Dosage, duration of intake, supportive medication and other environment influence the efficacy of probiotics. Sometimes undesirable symptoms can accompany use of probiotic especially supplements that may be due to transition phase in existing microbiota. Lowering the dose and hydration of the system can be supportive.

FAO UN/WHO (2001) Health and Nutritional Properties of Probiotics in Food including Powder Milk with Live Lactic Acid Bacteria. Report of a Joint FAO/WHO Expert Consultation on Evaluation of Health and Nutritional Properties of Probiotics in Food Including Powder Milk with Live Lactic Acid Bacteria

FAO UN/WHO (2002) Guidelines for the Evaluation of Probiotics in Food Report of a Joint FAO/WHO Working Group on Drafting Guidelines for the Evaluation of Probiotics in Food London Ontario, Canada.

\section{References}

1. Lara-Villoslada F, Olivares M, Sierra S, Rodriguez JM, Boza J, et al. (2007) Beneficial effects of probiotic bacteria isolated from breast milk. British Journal of Nutrition 98: 96-100.

2. Soccol CR (2010) The Potential of Probiotics: A Review. Food Technology and Biotechnology 48: 413-434. 